\title{
Electrocoagulation and Anodic Oxidation Integrated Process to Treat Leachate from a Portuguese Sanitary Landfill
}

\author{
D. Norma, A. Fernandes, M.J. Pacheco, L. Ciríaco* and A. Lopes \\ UMTP and Department of Chemistry, University of Beira Interior, 6201-001 Covilhã, Portugal
}

Received 14 September 2012; accepted 27 November 2012

\begin{abstract}
The electrochemical treatment of leachate samples from a Portuguese intermunicipal sanitary landfill was carried out using combined electrocoagulation/anodic oxidation processes. The electrocoagulation (EC) was performed with iron consumable anodes, at different initial $\mathrm{pH}$, with and without stirring, at different applied potentials. In the anodic oxidation (AO) assays, a boron-doped diamond anode was used and applied current densities of 10 to $30 \mathrm{~mA} / \mathrm{cm}^{2}$ were tested. The influence of the experimental conditions of the electrocoagulation pretreatment on the anodic oxidation performance was also assessed. In the EC assays the lowest iron and energy consumptions per mass of organic load removed were obtained at initial $\mathrm{pH}$ of 4 in the unstirred assays.

In the combined treatments, the highest average current efficiency in the anodic oxidation was obtained for the samples with $\mathrm{EC}$ pretreatment performed at $\mathrm{pH}$ of 6 . For the combined treatment with EC pretreatment run at natural $\mathrm{pH}$ of 8.6, an increase in AO current density led to a decrease in average current efficiency.
\end{abstract}

Keywords: landfill leachate; electrochemical treatments; electrocoagulation; anodic oxidation; BDD.

\section{Introduction}

The generation of municipal solid waste grows exponentially in urban society as a consequence of population growth, concentration of population in urban centres and new patterns of consumption. Sanitary landfills are the primary method currently used for municipal solid waste disposal in many countries [1]. One of the main problems generated by this common practice is the production of leachate [1]. It is a very complex wastewater containing different heavy metals, organic and inorganic compounds, some of them refractory and toxic, that possesses color and odor $[1,2]$. There is great concern about the contamination

\footnotetext{
*Corresponding author. E-mail: 1ciriaco@ubi.pt
} 
caused by landfill leachate, mainly because it is particularly difficult to treat. Thus, it is very important to apply reliable and effective treatment technology.

Conventional treatments (biological or physical-chemical) are not sufficient to reach the level of purification needed to eliminate the negative impact of landfill leachate on the environment. Membrane processes have proved to be a good solution to achieve full purification. However, these processes are restricted by treatment costs and membrane fouling [3]. Due to their effectiveness and ease in operation, electrochemical methods have recently received significant attention for wastewater treatment and several studies have reported the application of these methods in wastewater treatment [4-7].

Electrocoagulation (EC) is one of the electrochemical methods applied in the treatment of many types of wastewaters. A number of reports have described its application for wastewater treatment, including landfill leachate [8-12]. These studies have shown that electrocoagulation is a promising method to remove heavy metals, arsenic, dyes and other persistent pollutants that are hardly removed by conventional treatments [13]. Ilhan et al. [14] investigated the application of electrocoagulation to leachate treatment using aluminium and iron electrodes and showed that the electrocoagulation process has higher treatment performance than the chemical coagulation process and it can be successfully used as a step of a combined treatment.

The generation of metallic ions by EC is very dependent on the applied potential and on the characteristics of the wastewater, namely, the $\mathrm{pH}$ and the conductivity. The main processes that take place in the electrolytic system when iron anodes are used can be described by reactions (1) to (4). At the anode, the $\mathrm{Fe}^{2+}$ is present in the wastewater due to the oxidation of $\mathrm{Fe}$ according to reaction (1):

$$
\mathrm{Fe}_{(\mathrm{s})} \rightarrow \mathrm{Fe}^{2+}(\mathrm{aq})+2 \mathrm{e}^{-}
$$

At the cathode, $\mathrm{H}_{2}$ gas is formed from the reduction of proton in acidic medium (reaction 2) or from water reduction in alkaline medium (reaction 3). In both cases, the $\mathrm{pH}$ increases during electrolysis and the $\mathrm{Fe}^{2+}$ ion can react and form iron hydroxides (reaction 4):

$$
\begin{aligned}
& 2 \mathrm{H}^{+}{ }_{(\mathrm{aq})}+2 \mathrm{e}^{-} \rightarrow \mathrm{H}_{2(\mathrm{~g})} \\
& 2 \mathrm{H}_{2} \mathrm{O}_{(\mathrm{l})}+2 \mathrm{e}^{-} \rightarrow 2 \mathrm{OH}^{-}{ }_{(\mathrm{aq})}+\mathrm{H}_{2(\mathrm{~g})} \\
& \mathrm{Fe}^{2+}{ }_{(\mathrm{aq})}+2 \mathrm{OH}_{(\mathrm{aq})}^{-} \rightarrow \mathrm{Fe}(\mathrm{OH})_{2(\mathrm{~s})}
\end{aligned}
$$

In solution, iron ions hydrolyse and, depending on the medium $\mathrm{pH}$, different hydroxide mononuclear complexes may be formed. The insoluble $\mathrm{Fe}(\mathrm{OH})_{2}$ and $\mathrm{Fe}(\mathrm{OH})_{3}$ flocs have strong affinity for colloids, dispersed particles and ionic species and cause flocculation, which generates bigger particles. The formed flocs can be removed by sedimentation or flotation $[4,13]$.

Another promising electrochemical method used in wastewater treatment is the electrochemical oxidation that, in most of the existing studies, is applied as a post-treatment method. Deng and Englehardt [15] present an overview of electrochemical oxidation processes used to treat landfill leachates. Different 
types of anode materials (i.e. $\mathrm{TiO}_{2} / \mathrm{RuO}_{2}, \mathrm{PbO}_{2} / \mathrm{SnO}$, Ti/Pt, Ti/ $/ \mathrm{PbO}_{2}$ and borondoped diamond (BDD)) and the effect of several operating factors have been assessed [16,17], being the best results obtained with BDD anodes. Panniza and Cerisola [18] published a review of the results presented in the literature with this electrode in the past decade. This material has unique chemical, electrochemical and structural stabilities that allow its use at high potentials, where most organic pollutants can be oxidised [19]. More recently, Urtiaga et al. [20] reported the combination of activated sludge treatment with Fenton oxidation and electrooxidation with BDD anodes, at pilot scale, to treat a landfill leachate, where almost complete removal of the organic matter and ammonium nitrogen was achieved. A combination of biochemical treatment and electrochemical oxidation on a BDD electrode was also proposed, with promising results [21]. It was also described in the literature the application of electrochemical treatment to a stabilized leachate from a semi-aerobic sanitary landfill, using graphite carbon electrodes in the presence of sodium sulphate as electrolyte; high biochemical oxygen demand (BOD), chemical oxygen demand (COD) and color removals were achieved [22]. Although the results demonstrate that, under appropriate conditions, electrochemical oxidation can significantly eliminate organic contaminants, ammonia and color from leachate, the formation of undesirable oxidation by-products, such as nitrate anions and chlorinated organic compounds, has been detected [23]. Enormous advances have taken place in the development of electrochemical oxidation processes for landfill leachate; however more studies need to be done in order to optimize the efficiency of these processes.

The aim of this work was to evaluate the application of electrocoagulation and anodic oxidation as a combined treatment for a leachate from an intermunicipal sanitary landfill. The electrocoagulation was used as a first step, in order to remove colloidal and suspended particles, and it was followed by anodic oxidation to eliminate the remaining dissolved persistent organic compounds. In the electrocoagulation assays different experimental conditions were tested, in order to study their influence on the removal of organic matter: the initial $\mathrm{pH}$ of the samples that was varied in the ideal $\mathrm{pH}$ range for the application of electrocoagulation technique [13]; the existence of stirring, to find out also how it influences the time needed to electroprecipitate the suspensions; and the applied potential, to see if an increase in the rate of iron oxidation could lead to a more favourable energetic consumption.

\section{Materials and methods}

\section{Leachate samples}

The leachate samples used in this study were collected from an intermunicipal sanitary landfill, in two different seasons of the year, at the beginning of summer (L1) and at the beginning of winter (L2). The in situ treatment performed at the sanitary landfill comprises a biological step, followed by an ultrafiltration operation. The leachate samples were collected in the stabilization lagoon before 
the biological treatment, and kept refrigerated, in order to maintain its initial characteristics.

\section{Analytical determinations}

The samples collected at the leachate treatment plant and those from the electrochemical assays were analyzed, according to the procedures described in the standard methods [24], for the following parameters: Chemical oxygen demand, using closed reflux dichromate titrimetric method; Dissolved solids (DS); Suspended solids (SS); Total organic carbon (TOC) or dissolved organic carbon (DOC) (determined after filtration with a $1.2 \mu \mathrm{m}$ filter), measured using a TOC analyser, Shimadzu TOC-V CPH. UV-Visible absorption spectrophotometric analyses, with absorbance (Abs) measurements from 200 to $800 \mathrm{~nm}$, were also done, using a Shimatzu UV-1800 spectrophotometer. Measurements of $\mathrm{pH}$ and conductivity were carried out with a Mettler-Toledo $\mathrm{pH}$-meter and a Mettler-Toledo conductimeter, respectively.

\section{Electrochemical assays}

The cell used in the electrocoagulation study contained an iron anode, with an immersed area of $20 \mathrm{~cm}^{2}$, a stainless steel cathode of $16 \mathrm{~cm}^{2}$ and the distance between them was $2.3 \mathrm{~cm}$. The useful cell volume varies between 150 and 250 $\mathrm{mL}$ and experiments were conducted in batch mode. The electrodes were dipped into a vessel containing $150 \mathrm{~mL}$ of leachate. A constant voltage in the electrochemical cell was maintained using a DC power supply (GW, Lab DC, model GPS-3030D, 0 30V, 0 3 A). In order to calculate energy consumptions, current intensities were registered. All experiments were conducted at room temperature $\left(22-25^{\circ} \mathrm{C}\right)$ with no addition of background electrolyte. All the assays were run at least twice. In the cases where removals of COD (or DOC) of both assays differ from more than $10 \%$, assays were repeated, thus guaranteeing that standard deviations of the results presented for these parameters are less than or equal 10\%. The results presented are the medium of all the experiments performed.

With the aim of optimizing experimental conditions, different applied potentials, between 2 and $6 \mathrm{~V}$, were tested for L1 samples, at natural $\mathrm{pH}$ of 8.5. For L2 samples, several different initial $\mathrm{pH}$ conditions were also studied, namely, natural $\mathrm{pH}$ of 8.6 and $\mathrm{pH}$ of 4, 6 and 10, with applied potentials between 4 and $6 \mathrm{~V}$. All $\mathrm{pH}$ adjustments were done by the addition of concentrated $\mathrm{NaOH}$ or $\mathrm{H}_{2} \mathrm{SO}_{4}$ solutions. To study the effect of stirring in the process efficiency, all the experimental conditions mentioned above were tested with $(600 \mathrm{rpm})$ and without stirring. After various elapsed times, the electrocoagulated samples started to precipitate. When massive precipitation was no longer observed (10 to 50 minutes after starting the assay), current was turned off and the treated effluent was allowed to settle for $30 \mathrm{~min}$ and then the supernatant liquid was collected for the analytical determinations. Between experiments, the electrodes were washed, first with tap water and then with distilled water, to remove the sludge adsorbed on the electrode surface. 
The combined treatment, electrocoagulation followed by anodic oxidation (AO), was performed with $450 \mathrm{~mL}$ of leachate at the following electrocoagulation conditions: natural $\mathrm{pH}$ of 8.5, without stirring, for L1 samples; $\mathrm{pH} 6$ and 8.6 (natural), without stirring, for L2 samples. After the EC treatment, which took between 45 and $60 \mathrm{~min}$, the formed flocs were allowed to settle, and the suspension was decanted and subjected to filtration, in order to eliminate most of the suspended matter from the liquid mixture. This filtration avoids the unnecessary energy consume that would be used in the anodic oxidation of the organic matter present in the smaller flocs. The filtrate was then subjected to the anodic oxidation treatment.

Anodic oxidation experiments were conducted in batch mode, for $8 \mathrm{~h}$, with imposed current densities of 10, 20 and $30 \mathrm{~mA} \mathrm{~cm}{ }^{-2}$, using $200 \mathrm{~mL}$ of the electrocoagulated effluent. The useful cell volume varies between 100 and 300 $\mathrm{mL}$. A BDD anode, with an immersed area of $20 \mathrm{~cm}^{2}$, and a stainless steel cathode, with identical area, were used, being the distance between them $2 \mathrm{~cm}$. A GW, Lab DC, model GPS-3030D (0 30V, 0 3A), was used as power supply. Experiments were conducted at room temperature $\left(22-25^{\circ} \mathrm{C}\right)$ and samples were collected regularly, to perform the analytical determinations. All the AO were repeated twice and the values presented are the mean of the results obtained. Standard deviations for the samples collected in both assays, hourly, were calculated and they were always lower than 5\%. Between experiments, the cell was cleaned with a $\mathrm{NaCl}$ solution $0.1 \mathrm{M}$, for $10 \mathrm{~min}$, using an applied current density of $30 \mathrm{~mA} \mathrm{~cm}^{-2}$, and rinsed with 3 x $500 \mathrm{~mL}$ of distilled water.

\section{Results and discussion}

\section{Samples characterization}

Table 1 presents the characteristics of the leachate samples collected at the sanitary landfill. Although samples were collected in different seasons, COD is similar for L1 and L2. The most significant differences were observed in DOC content, being DOC value for L1 more than twice the value for L2. Since DOC is determined in the filtrate, the DS and conductivity are also higher for L1 samples.

Table 1. Characterization of the leachate samples collected in different seasons of the year.

\begin{tabular}{ccccccc}
\hline Sample & $\mathbf{C O D} / \mathbf{g ~ L}^{-1}$ & $\mathbf{D O C} / \mathbf{g ~ L}^{-\mathbf{1}}$ & $\mathbf{S S} / \mathbf{g ~ L}^{-1}$ & $\mathbf{D S} / \mathbf{g ~ L}^{-1}$ & $\mathbf{p H}$ & $\begin{array}{c}\text { Conductivity } \\
/ \mathbf{~ m S ~ c m}^{-1}\end{array}$ \\
\hline $\mathrm{L} 1$ & $12.97 \pm 0.05$ & $7.50 \pm 0.16$ & $0.94 \pm 0.03$ & $26.8 \pm 2.7$ & 8.5 & 31.4 \\
\hline $\mathrm{L} 2$ & $12.65 \pm 0.97$ & $2.88 \pm 0.07$ & $0.73 \pm 0.10$ & $19.6 \pm 0.5$ & 8.6 & 29.9 \\
\hline
\end{tabular}

\section{Electrocoagulation assays}

To study the influence of EC experimental conditions on the time needed to electroprecipitate the suspensions, and on the COD and DOC removal efficiency, different applied potentials were studied and the assays were performed with and without stirring. In fact, the applied potential is an important parameter in EC, 
since it determines the coagulant dosage and the size of the bubbles produced, and, consequently, the size and growth rate of the flocs. Table 2 presents the results obtained for the electrocoagulation assays performed with the L1 and L2 samples, at natural initial $\mathrm{pH}$ of, respectively, 8.5 and 8.6, with applied potentials of 4, 5 and $6 \mathrm{~V}$, with and without stirring. The results for the applied potentials of 2 and $3 \mathrm{~V}$ are not shown, since after $1 \mathrm{~h}$ assay any significant electroprecipitation of the suspensions was observed. The specific iron consumption, $\mathrm{Fe}_{\mathrm{sp}}$, in $\mathrm{g} \mathrm{L}^{-1}$, resulting from the oxidation of the anode, and the specific energy consumption, $\mathrm{E}_{\mathrm{sp}}$, in $\mathrm{W} \mathrm{h} \mathrm{L}^{-1}$, also presented in Table 2, were calculated according to the following equations:

$$
\begin{aligned}
& \mathrm{Fe}_{\mathrm{sp}}=\frac{\mathrm{I} \mathrm{t} \mathrm{M}_{\mathrm{Fe}}}{\mathrm{FnV}} \\
& \mathrm{E}_{\mathrm{sp}}=\frac{\mathrm{E} \mathrm{I} \mathrm{t}}{3600 \mathrm{~V}}
\end{aligned}
$$

where $\mathrm{I}$ is the current intensity, in $\mathrm{A}, \mathrm{t}$ is the electrocoagulation time, in $\mathrm{s}, \mathrm{M}_{\mathrm{Fe}}$ is the iron molar mass, in $\mathrm{g} \mathrm{mol}^{-1}, \mathrm{~F}$ is the Faraday constant, in $\mathrm{C} \mathrm{mol}^{-1}, \mathrm{n}$ is the number of electrons involved in Eq. $1, \mathrm{~V}$ is the volume of the sample, in $\mathrm{L}$, and $\mathrm{E}$ is the applied potential, in $\mathrm{V}$.

Table 2. Experimental results for the leachate samples collected in different seasons of the year, L1 and L2, subjected to electrocoagulation with iron anodes, at initial natural $\mathrm{pH}$ (8.5 for L1 and 8.6 for L2), performed with and without stirring and with different

\begin{tabular}{|c|c|c|c|c|c|c|c|c|c|c|c|c|}
\hline \multirow[b]{2}{*}{$\begin{array}{l}\text { Assay } \\
\text { number }\end{array}$} & \multicolumn{6}{|c|}{ L1 } & \multicolumn{6}{|c|}{$\mathbf{L 2}$} \\
\hline & A1 & A2 & A3 & A4 & A5 & A6 & B1 & B2 & B3 & B4 & B5 & B6 \\
\hline Stirring & & stirred & & & nstirre & & & stirred & & & instirre & \\
\hline $\mathrm{E} / \mathrm{V}$ & 4 & 5 & 6 & 4 & 5 & 6 & 4 & 5 & 6 & 4 & 5 & 6 \\
\hline $\begin{array}{l}\text { ECtime / } \\
\text { min }\end{array}$ & 50 & 40 & 30 & 25 & 30 & 20 & 30 & 20 & 15 & 20 & 30 & 10 \\
\hline $\mathrm{Fe}_{\mathrm{sp}} / \mathrm{g} \mathrm{L}^{-1}$ & 1.27 & 1.50 & 1.69 & 0.76 & 1.19 & 1.13 & 1.13 & 1.05 & 1.05 & 0.83 & 1.66 & 0.79 \\
\hline $\mathrm{E}_{\mathrm{sp}} / \mathrm{W} \mathrm{hL^{-1 }}$ & 4.9 & 7.2 & 9.8 & 2.9 & 8.6 & 6.5 & 4.3 & 5.0 & 6.0 & 3.2 & 8.0 & 4.6 \\
\hline $\mathrm{COD} / \mathrm{COD}_{0}$ & 0.92 & 0.94 & 0.87 & 0.86 & 0.83 & 0.86 & 0.81 & 0.80 & 0.99 & 0.81 & 0.67 & 0.83 \\
\hline $\mathrm{DOC} / \mathrm{DOC}_{0}$ & 0.71 & 0.67 & 0.87 & 0.85 & 0.87 & 0.85 & 0.87 & 0.85 & 0.96 & 0.87 & 0.75 & 0.83 \\
\hline $\mathrm{DS} / \mathrm{DS}_{0}$ & 0.99 & 0.98 & 0.98 & 0.99 & 0.98 & 0.99 & 0.98 & 0.99 & 0.99 & 0.99 & 0.93 & 1.00 \\
\hline$* \mathrm{C} / \mathrm{C}_{0}$ & 0.75 & 0.78 & 0.77 & 0.79 & 0.77 & 0.79 & 0.77 & 0.79 & 0.86 & 0.73 & 0.99 & 0.88 \\
\hline pH final** & 9.7 & 9.7 & 9.8 & 9.8 & 9.8 & 9.8 & 9.8 & 9.8 & 9.9 & 9.8 & 9.8 & 9.8 \\
\hline
\end{tabular}
applied potentials.

For the assays run at initial $\mathrm{pH}$ of 8.5 for L1 and 8.6 for L2 samples, the most significant COD removals were obtained without stirring, at an applied potential of $5 \mathrm{~V}$. In this case, it seems that the stirring makes the aggregates formation more difficult, delaying the precipitation of the suspended and dissolved matter. Regarding the influence of the applied potential, the highest iron and energy consumptions were obtained for the unstirred assays at $5 \mathrm{~V}$, which probably explains the highest COD removals obtained at that potential. Removals in DOC 
were good, being higher than COD removals for L1 samples and slightly lower for L2 samples. This fact must be related with the characteristics of the samples, since, for similar initial COD of L1 and L2, DOC for L1 is more than twice DOC for L2. In the case of DS, their values did not suffer significant changes. Regarding conductivity, a reduction was observed for all the assays performed, meaning that the solutions' constituents that most contribute to the conductivity of the solution had precipitated and also that the iron ions formed from the oxidation of the anode are being used in the precipitation of the organic matter. The lowest decrease in conductivity was observed for the assay with one of the highest specific iron consumptions (B5), meaning that this high conductivity must be due to the iron ions that were not used in the precipitation process.

Table 3. Experimental results for the leachate samples L2, subjected to electrocoagulation assays with iron anodes, performed in different experimental conditions: with and without stirring, at several initial $\mathrm{pH}$ and at various applied potentials.

\begin{tabular}{|c|c|c|c|c|c|c|c|c|c|c|c|c|}
\hline \multirow{3}{*}{$\begin{array}{l}\text { Assay number } \\
\text { Stirring }\end{array}$} & \multicolumn{6}{|c|}{ pH4 } & \multicolumn{6}{|c|}{ pH6 } \\
\hline & $\mathrm{C} 1$ & $\mathrm{C} 2$ & $\mathrm{C} 3$ & $\mathrm{C} 4$ & C5 & C6 & D1 & D2 & D3 & D4 & D5 & D6 \\
\hline & \multicolumn{3}{|c|}{ stirred } & \multicolumn{3}{|c|}{ unstirred } & \multicolumn{3}{|c|}{ stirred } & \multicolumn{3}{|c|}{ unstirred } \\
\hline $\mathrm{E} / \mathrm{V}$ & 4 & 5 & 6 & 4 & 5 & 6 & 4 & 5 & 6 & 4 & 5 & 6 \\
\hline ECtime / min & 55 & 50 & 30 & 40 & 40 & 30 & 50 & 50 & 30 & 55 & 40 & 30 \\
\hline $\mathrm{Fe}_{\mathrm{sp}} / \mathrm{g} \mathrm{L}^{-1}$ & 3.10 & 2.55 & 3.07 & 1.94 & 2.57 & 1.42 & 2.07 & 2.83 & 2.40 & 2.36 & 2.90 & 2.23 \\
\hline $\mathrm{E}_{\mathrm{sp}} / \mathrm{Wh} \mathrm{L^{-1 }}$ & 11.9 & 12.2 & 17.7 & 7.4 & 12.3 & 8.2 & 8.0 & 13.6 & 13.8 & 9.1 & 13.9 & 12.9 \\
\hline $\mathrm{COD} / \mathrm{COD}_{0}$ & 0.56 & 0.57 & 0.45 & 0.44 & 0.43 & 0.48 & 0.66 & 0.65 & 0.56 & 0.64 & 0.69 & 0.65 \\
\hline $\mathrm{DOC} \mathrm{DOC}_{0}$ & 0.65 & 0.57 & 0.51 & 0.58 & 0.54 & 0.56 & 0.79 & 0.78 & 0.74 & 0.88 & 0.80 & 0.97 \\
\hline $\mathrm{DS} / \mathrm{DS}_{0}$ & 1.50 & 1.70 & 1.50 & 1.77 & 1.54 & 1.68 & 1.28 & 1.31 & 1.27 & 1.32 & 1.25 & 1.03 \\
\hline$* \mathrm{C} / \mathrm{C}_{0}$ & 1.50 & 1.52 & 1.56 & 1.33 & 1.61 & 1.74 & 1.20 & 1.23 & 1.24 & 1.15 & 1.36 & 1.46 \\
\hline $\mathrm{pH}$ final** & 5.4 & 4.8 & 4.4 & 4.6 & 4.6 & 4.4 & 6.3 & 6.1 & 6.0 & 6.4 & 6.1 & 6.1 \\
\hline
\end{tabular}

\begin{tabular}{|c|c|c|c|c|c|c|}
\hline \multirow[b]{2}{*}{ Assay number } & \multirow[b]{2}{*}{ E1 } & \multirow[b]{2}{*}{ E2 } & \multicolumn{4}{|c|}{ pH10 } \\
\hline & & & E3 & E4 & E5 & E6 \\
\hline Stirring & & stirred & & & instirre & \\
\hline $\mathrm{E} / \mathrm{V}$ & 4 & 5 & 6 & 4 & 5 & 6 \\
\hline ECtime / min & 50 & 30 & 50 & 20 & 20 & 10 \\
\hline $\mathrm{Fe}_{\mathrm{sp}} / \mathrm{g} \mathrm{L}^{-1}$ & 1.39 & 2.06 & 1.96 & 0.95 & 1.00 & 0.79 \\
\hline $\mathrm{E}_{\mathrm{sp}} / \mathrm{Wh} \mathrm{L^{-1 }}$ & 5.3 & 4.9 & 11.3 & 3.6 & 4.8 & 4.5 \\
\hline $\mathrm{COD} / \mathrm{COD}_{0}$ & 0.90 & 0.92 & 1.00 & 0.94 & 0.94 & 0.97 \\
\hline $\mathrm{DOC} / \mathrm{DOC}_{0}$ & 0.90 & 0.88 & 0.91 & 0.92 & 0.92 & 0.90 \\
\hline $\mathrm{DS} / \mathrm{DS}_{0}$ & 1.34 & 1.46 & 1.38 & 1.32 & 1.32 & 1.37 \\
\hline${ }^{*} \mathrm{C} / \mathrm{C}_{0}$ & 1.31 & 1.21 & 1.11 & 1.21 & 1.13 & 1.03 \\
\hline $\mathrm{pH}$ final** & 11.9 & 11.9 & 11.8 & 11.9 & 11.9 & 11.9 \\
\hline
\end{tabular}

It has been established that solution or suspension's initial $\mathrm{pH}$ is an important factor which influences the performance of EC process [13]. Thus, L2 samples were subjected to electrocoagulation performed with different initial $\mathrm{pH}$, besides the initial natural $\mathrm{pH}$ of 8.6. The results obtained for the variation of the several parameters used to follow the assays are presented in Table 2 (initial $\mathrm{pH}$ of 8.6) and Table 3 (initial $\mathrm{pH}$ of 4,6 and 10). In the electrocoagulation assays designated $\mathrm{B}$ to $\mathrm{E}$, the stirring has no marked influence on the COD and TOC removal efficiency and the best COD and DOC removals were obtained for the 
assays run at initial $\mathrm{pH}$ of 4 . In general, during EC, it was observed an increase on DS values, being the highest increase obtained for initial $\mathrm{pH}$ of 4 . This observation may be related with the introduction of sulphuric acid, used to correct the initial $\mathrm{pH}$. Also, with this initial $\mathrm{pH}$ the final conductivity was the highest, due to the same reason. A significant increase in $\mathrm{pH}$ was observed in the final suspension of all the assays performed (data not shown). However, this increase was significantly lower in the filtrate of the electrocoagulation effluent (Tables 2 and 3). So, for the assays run at initial $\mathrm{pH}$ of 4, although the best COD and DOC removals were attained, the final result is a suspension that is not easily settled, with a very low $\mathrm{pH}$ and a very high conductivity. For the assays run at initial $\mathrm{pH}$ of 6 , the lowest final COD and DOC observed were obtained in the assays run with stirring, which also promotes a slight tendency to increase final DS and to decrease final conductivity, when compared with the assay run without stirring, showing almost no effect on the final $\mathrm{pH}$. The assays run with basic suspensions, $\mathrm{pH}$ of 8.6 and 10 are those that present results with the same trend, with low COD and DOC removals and a small increase in the final $\mathrm{pH}$. As mentioned previously, the influence of stirring is not very pronounced for these runs and the main difference is observed at $\mathrm{pH}$ of 8.6 , where the absence of stirring promotes a quicker settling. The assay run at $\mathrm{pH}$ of 8.6, without stirring and with an applied potential of $5 \mathrm{~V}$ (assay B5) has shown particular very good settling properties, being, however, the assay with the highest iron and energy consumptions among those performed at initial $\mathrm{pH}$ of 8.6.
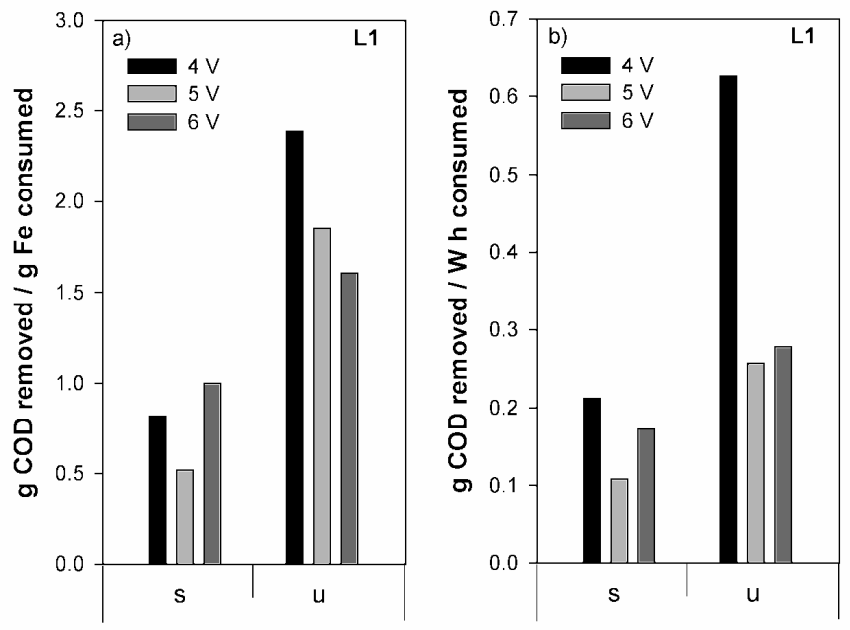

Figure 1. Ratios of COD removed by iron (a) and energy (b) consumptions for the electrocoagulation assays performed with leachate $\mathrm{L} 1$ at natural initial $\mathrm{pH}$ of 8.5 , with and without stirring and different applied potentials.

When the results of all the assays performed with L2 samples are compared, we may draw the following conclusions: although initial $\mathrm{pH}$ of 4 gives the highest load removals, the final solutions present very low $\mathrm{pH}$ and very high conductivity; for initial $\mathrm{pH} 10$, the load removal is poor and final $\mathrm{pH}$ and conductivity are high; only assays run at $\mathrm{pH}$ of 8.6 present a reduction in the conductivity; regarding the iron consumption, there is a tendency to a decrease in 
the iron needed to promote the flocculation with the increase in initial $\mathrm{pH}$; in most assays performed at equal initial $\mathrm{pH}$ and applied potential, the energy consumption increases with stirring; regarding the influence of the applied potential, in most of the cases, an increase in the applied potential leads to a decrease in the time needed to form flocs with critical size $\left(\mathrm{EC}_{\mathrm{time}}\right)$, i.e., with enough mass to precipitate.
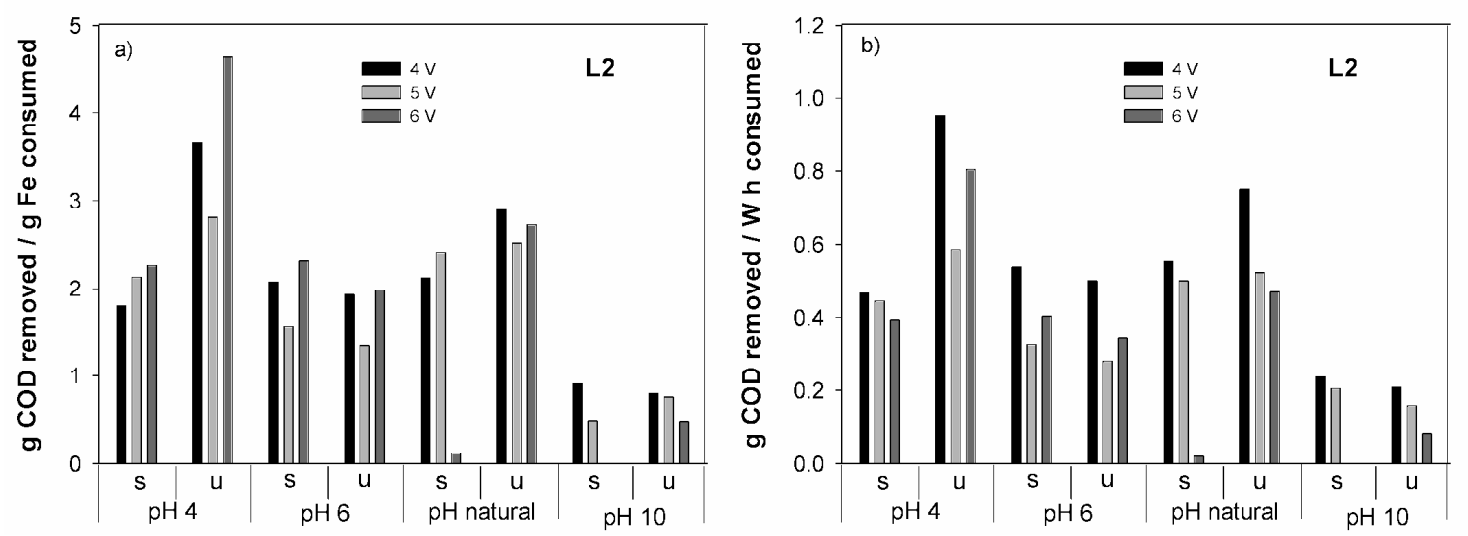

Figure 2. Ratios of COD removed by iron (a) and energy (b) consumption for the electrocoagulation assays performed with leachate $\mathrm{L} 2$ at different initial $\mathrm{pH}$, stirring conditions and applied potentials.

In Fig. 1 the specific removals in COD, i.e., COD removed per iron consumed and COD removed per energy consumption, for the different assays run with samples L1, are plotted. The most economical treatments, either in iron or in energy consumptions, were obtained for the unstirred assays. Identical results of those presented in Fig. 1 for L1 samples are presented in Fig. 2 for the assays run with samples L2, for all the initial $\mathrm{pH}$ tested. The specific removals in COD are very dependent on the time necessary to observe the flocculation, and, in general, this time increased with stirring. Regarding the influence of initial $\mathrm{pH}$, the most economical solutions, in terms of iron and energy consumptions, are obtained in the unstirred assays, at $\mathrm{pH} 4$ and 8.6, by this order. However, according to literature, at $\mathrm{pH}$ lower than 5 the amount of iron dissolved from the anode is higher than the one expected from Faraday's law due to chemical attack of the anode by protons [25]. This way, the results obtained at this $\mathrm{pH}$ may be due to an extra quantity of dissolved iron that can be used in the precipitation of the organic matter.

\section{Anodic oxidation assays}

Since in the results obtained by EC the COD removal efficiencies were relatively low, further treatment is required in order to eliminate dissolved organic compounds. In this work, it was proposed to treat the leachate using combined processes, an EC pretreatment followed by anodic oxidation using a BDD anode. The EC's pretreatment conditions chosen for the combined treatment were: $\mathrm{pH}$ of 8.6, because it does not require addition of chemicals; no stirring, because it leads to quicker settling; applied potential of $5 \mathrm{~V}$, since it is the applied potential that led to a higher COD+DOC removal. 


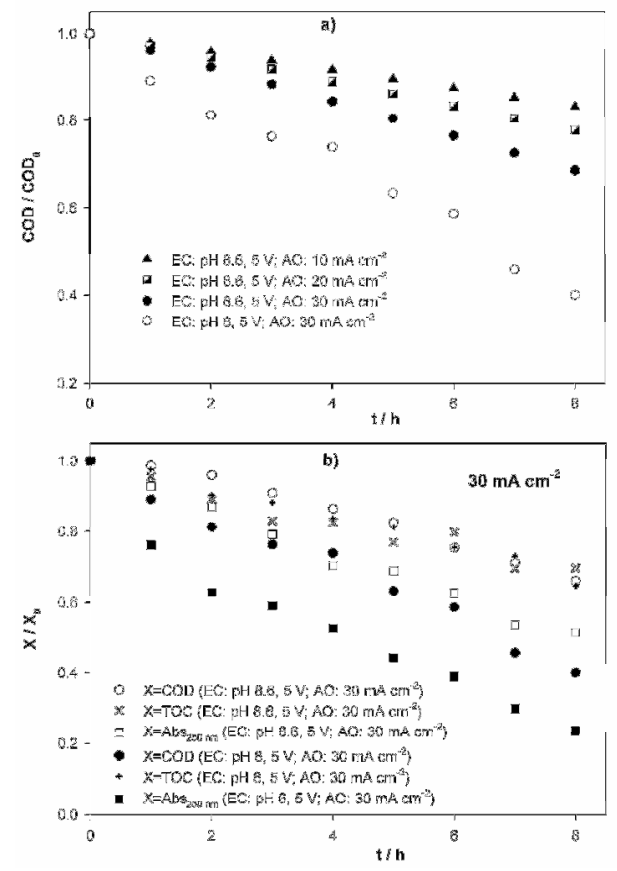

Figure 3. (a) Variation of relative COD with time and (b) decays of relative COD, TOC and Abs in time, measured at $250 \mathrm{~nm}$, for the anodic oxidation assays run at different current densities, performed with leachate samples submitted to different electrocoagulation pretreatments (initial $\mathrm{pH}$ of 6 and 8.6).

The anodic oxidation was performed at current densities of 10,20 and $30 \mathrm{~mA}$ $\mathrm{cm}^{-2}$ for the samples with EC pretreatment performed at initial $\mathrm{pH}$ of 8.6 and at $30 \mathrm{~mA} \mathrm{~cm}{ }^{-2}$ for the sample with EC performed at initial $\mathrm{pH}$ of 6 . The decays with time of COD, TOC and Abs, measured at $250 \mathrm{~nm}$, for those assays are presented in Fig. 3. COD removals increase with applied current density and, for equal applied current density, the COD decay with time is much higher for the assay with the EC pretreatment performed at acid $\mathrm{pH}$. However, TOC removal wasn't influenced by the EC pretreatment. This means that the pretreatment influences the way how the mixture undergoes oxidation, without changing the tendency for the mineralization of the compounds present in the suspension. Apparently, a pretreatment at acidic $\mathrm{pH}$ predisposes the mixture to an easier oxidation. Another conclusion that can be drawn from data presented in Fig. $3 \mathrm{~b}$ is that COD and TOC decays for the AO assay performed at $30 \mathrm{~mA} \mathrm{~cm}$, with an EC pretreatment executed at $\mathrm{pH}$ of 8.6, are very similar, pointing to a high degree of mineralization of the organic matter. This tendency was not observed for the AO assay of the sample that had had an EC pretreatment performed at $\mathrm{pH}$ of 6 , where removals of COD and TOC were completely different. Regarding the Abs variation with time, it presents the highest decay of all the evaluated parameters, being higher for the $\mathrm{AO}$ with the EC pretreatment performed at $\mathrm{pH}$ of 6 (Fig. 3 b). Considering these applied current densities, and since the initial COD content of the samples was high, the degradation process must be controlled by the current. To elucidate this, typical mean mass transfer coefficients, $\mathrm{k}_{\mathrm{m}}$, for this type of samples were obtained from literature $\left(\mathrm{k}_{\mathrm{m}}=1.75 \times 10^{-5} \mathrm{~m} \mathrm{~s}^{-1}\right.$ [23] or 2.74 $\times 10^{-5} \mathrm{~m} \mathrm{~s}^{-1}$ [26]) and used to calculate the critical COD, $\mathrm{COD}_{\mathrm{cr}}$ [27], i.e., the 
lowest COD value that, at the applied current density, j, of $30 \mathrm{~mA} \mathrm{~cm}$, guarantees the current control, using the following equation:

$$
\mathrm{COD}_{\mathrm{cr}}=\frac{\mathrm{j}}{4 \mathrm{~F} \mathrm{k}_{\mathrm{m}}}
$$

where $\mathrm{k}_{\mathrm{m}}$ is in $\mathrm{m} \mathrm{s}^{-1}$. The values of $\mathrm{COD}_{\mathrm{cr}}$ thus obtained are 910 and $1420 \mathrm{mg} \mathrm{L}^{-1}$, showing that, in fact, the anodic oxidations performed were mainly controlled by current. This way, an increase of COD removal with current density was expected, according to Eq. 8 [27]:

$$
\mathrm{COD}_{\mathrm{t}}=\mathrm{COD}_{0}-\frac{8 \mathrm{I}}{\mathrm{FV}} \mathrm{t}
$$

where $\mathrm{V}$ is in $\mathrm{m}^{3}$ and COD in $\mathrm{mg} \mathrm{L}^{-1}$. For the studied samples obtained from the EC treatment at initial $\mathrm{pH}$ of 8.6, as already referred, removals of COD and TOC and absorbance decay increase with current density. However, the observed increase in COD removal with current density was much lower than the expected/theoretical, predicted by Eq. 8, as can be seen in Fig. 4, where the theoretical slope of Eq. 8 is represented, as well as the experimental values for $\mathrm{COD}_{0}-\mathrm{COD}_{\mathrm{t}}$ vs. time and the correspondent fits of linear equations to the experimental values. There are two main reasons for this discrepancy between theoretical and observed values: a not so good adjustment of Eq. 8 to experimental data, since it was deduced for organic compounds and not for such a complex mixture as leachates are; and the high formation of humic and fulvic substances [28] that may promote the fouling of the electrode's surface. Regarding this last hindrance, it can be overcome with an increase in current density that increases the applied potential and reduces fouling. However, this increase in current density may lead to a decrease in the average current efficiency, ACE, (Table 4), calculated using the following equation [27]:

$$
\mathrm{ACE}=100 \mathrm{~F} \mathrm{~V}\left(\frac{\mathrm{COD}_{\mathrm{t}}-\mathrm{COD}_{0}}{8 \mathrm{I} \Delta \mathrm{t}}\right)
$$

For the current density of $30 \mathrm{~mA} \mathrm{~cm} \mathrm{~cm}^{-2}$, AO assays were also performed with samples obtained from an EC pretreatment run at initial $\mathrm{pH}$ of 6 , without stirring and at an applied potential of $5 \mathrm{~V}$. The obtained results, also presented in Table 4 and Fig. 3 and 4, have shown that anodic oxidation assays performed with the sample obtained in EC pretreatment with initial $\mathrm{pH}$ of 6 gave better overall removals of COD and higher current efficiency than those with EC performed at $\mathrm{pH}$ of 8.6. 


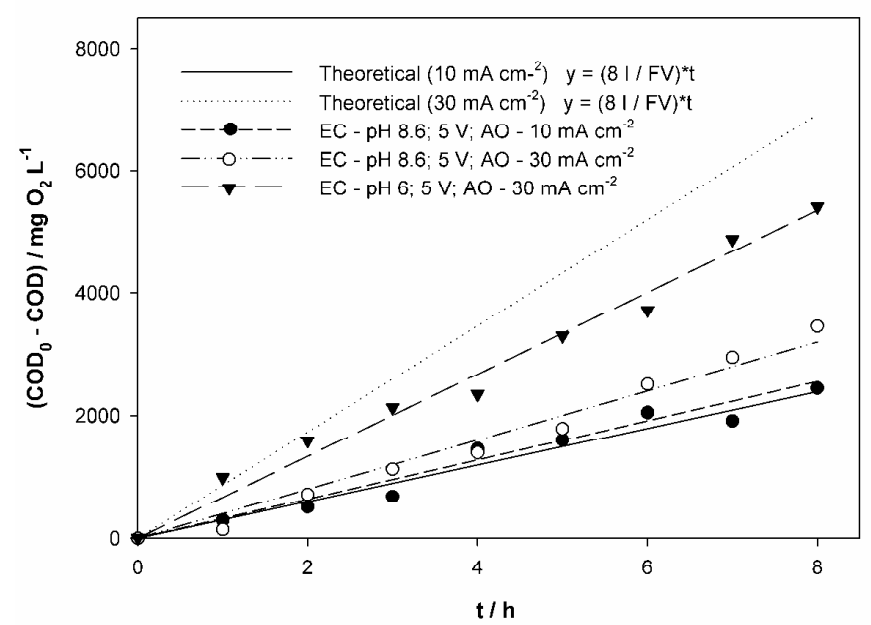

Figure 4. Experimental and theoretical COD absolute removals as a function of time for the anodic oxidation assays performed at 10 and $30 \mathrm{~mA} \mathrm{~cm}^{-2}$ with leachate samples submitted to different electrocoagulation pretreatments (initial $\mathrm{pH}$ of 6 and 8.6).

Table 4. Overall results for the samples subjected to electrocoagulation, at $5 \mathrm{~V}$ and different initial $\mathrm{pH}$, with iron anodes, followed by anodic oxidation with BDD.

\begin{tabular}{|c|c|c|c|c|}
\hline \multicolumn{3}{|c|}{ Electrocoagulation pretreatment conditions } & pH 8.6 (natural) & pH 6 \\
\hline \multicolumn{2}{|c|}{ Anodic oxidation experimental conditions } & \multicolumn{3}{|c|}{$200 \mathrm{~mL} ; 8 \mathrm{~h}$} \\
\hline \multirow[b]{2}{*}{$\mathrm{j}=10 \mathrm{~mA} \mathrm{~cm}^{-2}$} & $\mathrm{ACE}(\mathrm{AO}) / \%$ & & 100 & \\
\hline & Total removal $(\mathrm{EC}+\mathrm{AO}) / \%$ & $\begin{array}{l}\text { COD } \\
\text { TOC }\end{array}$ & $\begin{array}{l}33 \\
40 \\
\end{array}$ & $\begin{array}{l}-- \\
-- \\
\end{array}$ \\
\hline \multirow[b]{2}{*}{$\mathrm{j}=20 \mathrm{~mA} \mathrm{~cm}^{-2}$} & $\mathrm{ACE}(\mathrm{AO}) / \%$ & & 62 & \\
\hline & Total removal $(\mathrm{EC}+\mathrm{AO}) / \%$ & $\begin{array}{l}\text { COD } \\
\text { TOC }\end{array}$ & $\begin{array}{l}47 \\
42 \\
\end{array}$ & $\begin{array}{l}-- \\
-- \\
\end{array}$ \\
\hline \multirow[b]{2}{*}{$\mathrm{j}=30 \mathrm{~mA} \mathrm{~cm}^{-2}$} & $\mathrm{ACE}(\mathrm{AO}) / \%$ & & 45 & 75 \\
\hline & Total removal $(\mathrm{EC}+\mathrm{AO}) / \%$ & $\begin{array}{l}\text { COD } \\
\text { TOC }\end{array}$ & $\begin{array}{l}47 \\
43\end{array}$ & $\begin{array}{l}72 \\
43\end{array}$ \\
\hline
\end{tabular}

In Fig. 4 it can also be observed that the assay run at the lowest current density fits quite well the theoretical line, which explains the ACE of 100\%. Regarding the assays run at the highest current density, the one that best approaches the ideal behaviour is that with the EC pretreatment performed at $\mathrm{pH}$ of 6 , with a higher ACE.

\section{Conclusion}

According to the obtained results, the application of combined electrochemical techniques, namely electrocoagulation and anodic oxidation, seems feasible for the treatment of leachates from sanitary landfills.

Regarding the electrocoagulation assays, the best specific COD removals per iron or per energy consumptions were obtained at the following experimental conditions: initial $\mathrm{pH}$ of 4 and 8.6 , by this order, in the unstirred assays. In general, the use of stirring increases the time needed to start, with a visible rate, the precipitation of the flocs formed in the electrocoagulation. However, this time 
is reduced by an increase in applied potential, due to a higher rate of iron oxidation.

For the electrocoagulation treatments, performed at natural initial $\mathrm{pH}$ (8.5 for $\mathrm{L} 1$ and 8.6 for L2), seasonality does not seem to have a big impact in the iron and energy consumptions for the studied samples, being slightly more favourable for L2 samples.

The best results in the combined treatment were attained with the highest applied current density. It was observed that the global organic carbon removal does not clearly depend on the electrocoagulation experimental conditions. However, the total COD removal is influenced by the electrocoagulation pretreatment conditions, as well as the average current efficiency, that for the highest applied current density presented better results when the electrocoagulation pretreatment was performed at $\mathrm{pH}$ of 6 .

\section{Acknowledgements}

Financial support from FEDER, through Programa Operacional Factores de Competitividade - COMPETE, and FCT, for the project PTDC/AACAMB/103112/2008 and for the grant awarded to A. Fernandes, SFRH/BD/81368/2011, are gratefully acknowledged.

\section{References}

1. Eggen T, Moeder M, Arukwe A. Sci Total Environ. 2010;408:5147-5157.

2. Öman CB, Junestedt C. Waste Manage. 2008;28:1876-1891.

3. Abbas AA, Jingsong G, Ping LZ, Ya PY, Al-Rekabi WS. J Appl Sci Res. 2009;5:534-545.

4. Chen G. Sep Purif Technol. 2004;38:11-41.

5. Martínez-Huitle CA, Ferro S. Chem Soc Rev. 2006;35:1324-1340.

6. Comninellis C, Kapalka A, Malato S, Parsons SA, Poulios I, Mantzavinos D. J Chem Technol Biotechnol. 2008;83:769-776.

7. Panizza M, Cerisola G. Chem Rev. 2009;109:6541-6569.

8. Mollah MYA, Morkovsky P, Gomes JAG, Kesmez M, Parga J, Cocke DL. J Hazard Mat B. 2004;114:199-210.

9. Ün ÜT, Ugur S, Koparal AS, Ögütveren ÜB. Sep Purif Technol. 2006;52:136-141.

10. Hansen HK, Nunez P, Raboy D, Schippacasse I, Grandon R. Electrochim Acta. 2007;52:3464-3470.

11. Zongo I, Maiga AH, Wéthé J, Valentin G, Leclerc J-P, Paternotte G, Lapicque F. J Hazard Mat. 2009;169:70-76.

12. Labanowski J, Pallier V, Feuillade-Cathalifaud G. J Hazard Mat. 2010;179:166-172.

13. Liu H, Zhao X, Qu J. Electrocoagulation in water treatment (ch 10). In: Comninellis C, Chen G, editors. Electrochemistry for the environment, Springer Science+Business Media. New York. LLC; 2010. p.245-262.

14. Ilhan F, Kurt U, Apaydin O, Gonullu MT. J Hazard Mat. 2008;154:381389. 
15. Deng Y, Englehardt JD. Waste Manage. 2007;27:380-388.

16. Anglada A, Urtiaga A, Ortiz I. J Chem Technol Biotechnol. 2009;84:17471755.

17. Ghernaout D, Naceura MW, Aouabeda A. Desalination. 2011;270:9-22.

18. Panizza M, Cerisola G. Electrochim Acta. 2005;51:191-199.

19. Luong JHT, Male KB, Glennon JD. Analyst. 2009;134:1965-1979.

20. Urtiaga A, Rueda A, Anglada Á, Ortiz I. J Hazard Mat. 2009;166:15301534.

21. Zhao G, Pang Y, Liu L, Gao J, Lv B. J Hazard Mat. 2010;179:1078-1083.

22. Bashir MJK, Isa MH, Kutty SRM, Awang ZB, Aziz HA, Mohajeri S, Farooqi IH. Waste Manag. 2009;29:2534-2541.

23. Anglada A, Urtiaga A, Ortiz I, Mantzavinos D, Diamadopoulos E. Water Res. 2010;45:828-838.

24. Eaton A, Clesceri L, Rice E, Greenberg A, Franson MA. Standard methods for examination of water and wastewater. $21^{\text {st }}$ ed. Washington, DC: American Public Health Association; 2005.

25. Martínez-Huitle CA, Brillas E. Appl. Catalysis B-Environment. 2009;87:105-145.

26. Fernandes A, Pacheco MJ, Ciríaco L, Lopes A. J Hazard Mat. 2012;199200:82-87.

27. Comninellis C, Pulgarin C. J Appl Electrochem. 1991;21:703-708.

28. Cataldo F. Polym Int. 1998;46:263-268. 